\title{
The search for the development of clusters in Tamaulipas, Mexico: A case study*
}

\author{
Karla Paola Jiménez Almaguer,** José Melchor Medina Quintero*** \\ y Nazlhe Faride Cheín Schekaibán****
}

\begin{abstract}
The advantages of industrial clusters as propenners of development have been widely noted. These advantages have prompted various administrations to propose the creation of clusters as a development policy. The state of Tamaulipas, Mexico has not been an exception. The purpose of this paper is to analyze the impact of environmental factors, cluster characteristics, and on the performance of cluster companies, particularly, in four industrial clusters in Tamaulipas (petrochemical, auto parts, electric-electronic, and information technology). Based on in-depth interviews with members and participants, our findings suggest that the performance of these cluster comes from geographical location advantages, sociocultural identity, internal networks, specialization, and human capital training; that knowledge sharing is discretionary, and that the region still needs research support (research institutions and government agencies). However, the case studies show that policy makers, firms and knowledge institutions should work in mutual understanding to improve clusters absorptive capacity in order to increase innovative capacity.
\end{abstract}

Keywords: industrial clusters, regional development, public policies, cluster performance. JEL classification: L16, O40, R11.

\section{RESUMEN}

Mucho se ha discutido sobre las virtudes de los conglomerados (clusters) para el desarrollo. Esto ha motivado que distintas administraciones se propongan su creación. El propósito de este trabajo es analizar el impacto de diferentes factores ambientales, de las características de los conglomerados y de las empresas que los integran en su desempeño. Específicamente, en los conglomerados industriales de Tamaulipas, México (petroquímica, automotriz, eléctrico-electrónico y tecnologías de la información). Sobre la base de entrevistas a fondo con los miembros y participantes, nuestros resultados sugieren que el desempeño es resultado de su ubicación geográfica, identidad sociocultural, redes internas, especialización y formación del capital humano, aunque el intercambio de conocimientos es discrecional, y se necesita apoyo a la investigación (institutos de investigación y agencias gubernamentales). Asimismo, los estudios de caso muestran que los participantes deben trabajar en el entendimiento mutuo para aumentar la capacidad innovadora.

Palabras clave: conglomerados industriales, desarrollo regional, políticas públicas, desempeño de conglomerados.

Clasificación JEL: L16, O40, R11.

\footnotetext{
* Fecha de recepción: 09/08/2012. Fecha de aprobación: 29/04/2013.

** Profesora-investigadora de la Facultad de Comercio y Administración-Tampico de la Universidad Autónoma de Tamaulipas. Correo electrónico: kjimenez@uat.edu.mx.

*** Profesor-investigador de la Facultad de Comercio y Administración-Victoria de la Universidad Autónoma de Tamaulipas. Correo electrónico: jmedinaq@uat.edu.mx.
} 


\section{INTRODUCTION}

Clusters have been part of the economic landscape for a long time, since the geographical concentrations of craftsmen and companies engaged in any activity have existed for centuries. However, it can be said today that, with the evolving competition and competitiveness of national economies, the depth and the breadth of clusters have increased. Globalization, coupled with the mounting importance of growth, has changed the role of clusters in competition (Porter, 1999; Yeung, Liu and Dicken, 2006).

During the last decade of the twentieth century, clusters were admitted as scenarios to stimulate productivity and innovation in companies that integrate them or for training and for the creation of new businesses (Masiá et al., 2004). As critical mass of unusual competitive success in particular business areas, clusters are a striking feature of almost every national economy, even of regional and metropolitan areas, especially in the more economically advanced countries. Although the reasons in the past that led to the creation of clusters have lost importance due to globalization, the new role that these play in competition is becoming increasingly important in the context of a knowledge-based economy (Porter, 1999); even in developing countries like Mexico (Dávila, 2008). In many countries, a new form of economic geography has been developed, and public policies have been designed to promote the creation of clusters (Mixteo, Idigoras and Vicente, 2004). Consequently, their performance has generated interest from academics, entrepreneurs, and policy makers around the world (McCann, 2008). In this sense, it is necessary to discuss many issues to help clarify the phenomenon of clusters. One of the most important ones is to identify the factors that may lead to their performance.

Although literature on clusters indicates the advantages of geographical firms agglomeration, research that review their performance are scarce (Malmberg, Malmberg and Lundequist, 2000; Beaudry and Breschi, 2003). This paper tries to shed some light on the relationship between cluster elements and performance by analysing how location features, dependence on firm's, and clusters'

\footnotetext{
**** Profesora-investigadora de la Facultad de Comercio y Administración-Tampico de la Universidad Autónoma de Tamaulipas. Correo electrónico: nchein@uat.edu.mx.

Paper presented at the $12^{\text {th }}$ International Conference of the Society for Global Business and Economic Development (SGBED), Singapore, July 21-23, 2011. The authors are grateful to Fondo Mixto de Fomento a la Investigación Científica y Tecnológica CONACYT-Gobierno del Estado de Tamaulipas, for their support (under the program Difusión y Divulgación Científica y Tecnológica).
} 
characteristics affect firm's outputs. In order to achieve the objective of this paper, empirical evidence is derived from four case studies in Tamaulipas, Mexico (petrochemical, auto parts, electric-electronic, and information technology). This paper is structured as follows: section I develops the theoretical background for the case studies, section II describes the four clusters in Tamaulipas, section III details the research methods used in this paper, section IV lays the empirical foundation of the paper based on the information gained from the authors' observation and intensive sessions with key players in each cluster, and the final section draws conclusion and provides implications.

\section{THEORETICAL FOUNDATIONS}

Cluster analysis has attracted considerable attention in the theoretical, methodological and political environments, especially since the early 1990's. This continued the research developed on the 1980's of agglomerations in regions (Piore and Sabel, 1983, 1984; Scott and Storper, 1987; Scott, 1988; Sabel, 1989; Storper and Scott, 1989). At the same time, the studies of Porter $(1990,1998)$ on clusters have been very influential. Furthermore, literature on clusters covers different areas of research: social sciences, regional economics, economic geography, political economy, and industrial organization (Yang and Stough, 2005).

Hence, the influence of clusters has evolved as a field of considerable interest in academic research in the last fifteen years (Freeman, 1987; Lundvall, 1992; Nelson, 1993; Edquist and McKelvey, 2000). Therefore, several studies have developed important concepts and models to explain the reasons of clusters competitiveness, among which are: industrial atmosphere (Marshall, 1919) (later formalized by Becattini (1987) and Krugman (1991)); localized external economies (Marshall, 1920); flexible specialization (Piore and Sabel, 1984); and the innovative environment developed by the GREMI (Groupe de Recherché Européen sur le Milllieux Innovateurs) (Porter, 1990; Maillat, et al., 1995; Keeble et al., 1999; Albino, Carbonara and Giannoccaro, 2005). Also, many published empirical analysis have described and analyzed the processes and functionality of clusters (Saxenian, 1995; Porter, 1998; Karim and Mitchell, 2000; Bathelt, 2001; Masiá et al., 2004; Albino, Carbonara and Giannoccaro, 2005; Lee and Von Tunzelmann, 2005; Lembke and Östhol, 2005; Menzel, 2005).

According to the consulted research, cluster performance is influenced by different factors that are present in the economic and social environment, in the cluster characteristics, and in the cluster companies. After analyzing the im- 
portance and the effects of these dimensions on the development of clusters, we classified these factors into three categories: a) the environment, b) characteristics of the cluster, and c) intrinsic factors of cluster firms (Table 1).

Table 1. Causes of cluster development

\begin{tabular}{|l|l|c|}
\hline \multicolumn{1}{|c|}{$\begin{array}{c}\text { Causes related to the } \\
\text { cluster's environment }\end{array}$} & $\begin{array}{c}\text { Causes related to the } \\
\text { cluster's characteristics }\end{array}$ & $\begin{array}{c}\text { Causes intrinsic to the } \\
\text { business that developed } \\
\text { the cluster }\end{array}$ \\
\hline Location & Research Agencies & Specialization \\
Social Capital & - Universities & Human Capital \\
< Role of Public Administrations & - Technology Centers & - Knowledge Management \\
- Public Policies & - Public Agencies & Exchange of Kknowledge \\
< Sociocultural Identity & Internal Services & Capital \\
Local Demand & Internal Networks & \multicolumn{2}{|l}{} \\
\hline
\end{tabular}

\section{Environmental factors}

Firstly, within the environmental factors, geographic location may provide advantages for the cluster and for the companies due to (1) economies of agglomeration created in the area (Folta, Cooper and Yoon-suk, 2006; Soler, 2006; Silvestre and Tavares, 2009; Diez-Vial, 2011; Libaers and Meyer, 2011; Li and Geng, 2012; Molina-Morales and Expósito-Langa, 2012; Mukim, 2012; Munari, Sobrero and Malipiero, 2012), (2) the openness and competitiveness of the region (Pandit and Cook, 2005; Liao, 2010), and (3) the externalities of the region (Baptista and Swann, 1998; Grando and Belvedere, 2006; Cotic-Svetina, Jaklic and Prodan, 2008).

Also, in the last decade, great emphasis was given to social capital and its influence on growth and the development of companies (Nahapiet and Ghoshal, 1998; Nielsen, 2003). Therefore, the role of government has been considered relevant for the cluster, especially through public policies to obtain: (1) support through financing (Romijn and Albaladejo, 2002; Manning et al., 2010), (2) the establishment of research and development centers (Yamawaki, 2002), and (3) the promotion of networks and foreign direct investment (Kim, 2005; Nishimura and Okamuro, 2011; Barbieri, Tommaso and Bonnini, 2012; Richardson, Yamin and Sinkovics, 2012).

Similarly, an element that takes the shape of formal networks among individuals is the sociocultural identity, which greatly simplifies access to resour- 
ces and information as a result of trust and cooperation (Nicolini, 2001; Liao, 2010), and benefits companies due to knowledge transfer (Nassimbeni, 2001; Cotic-Svetina, Jaklic and Prodan, 2008; Kong, 2011; Liu, 2011; Nishimura and Okamuro, 2011; Kamnungwut and Guy, 2012; Molina-Morales, et al., 2012; Nakwa, Zawdie and Intarakumnerd, 2012; Ng and Thiruchelvam, 2012; Gebreeyesus and Mohnen, 2013). Moreover, an important aspect of the cluster's environment is the local demand, as it symbolizes the first challenge and encourages its exit to larger markets (Rabellotti, 1997; Nicolini, 2001; Diez-Vial, 2011).

\section{Clusters characteristics}

Clusters have features that define and affect their performance. Close relationships with universities are decisive, either for training or supporting entrepreneurs with infrastructure and knowledge (Albino, Carbonara and Giannoccaro, 2005; Romijn and Albaladejo, 2002; Manning et al., 2010; Libaers and Meyer 2011; Hervas-Oliver et al., 2012). In addition, cooperation with research institutes is crucial to the successful design of innovations within clusters (Albino, Carbonara and Giannoccaro, 2005; Romijn and Albaladejo, 2002; Hervas-Oliver et al., 2012; Barbieri, Tommaso and Bonnini, 2012; Nakwa, Zawdie and Intarakumnerd, 2012). Similarly, government agencies can promote the technological development of companies that integrate clusters and can help trade ideas and inventions (Yamawaki, 2002; Lembke and Östhol, 2005; Manning et al., 2010; Sarvan et al., 2011; Nakwa, Zawdie and Intarakumnerd, 2012; Ng and Thiruchelvam, 2012).

Likewise, internal services inside the cluster provide access to regional know-how (Nicolini, 2001; Gabaldón-Estevan and Fernández-de-Lucio, 2006; Manning et al., 2010). In the same way, internal networks are the most common form of cooperation, they affect the competitiveness and increase: (1) the cluster skills (Saxenian, 1995; Martínez del Río and Céspedes-Lorente, 2006), (2) the flow of information (Bell, 2005; Fuchs and Koch, 2005; Liao, 2010; Liu, 2011; Kong 2011; Sarvan et al., 2011; Molina-Morales et al., 2012; $\mathrm{Ng}$ and Thiruchelvam, 2012; Gebreeyesus and Mohnen, 2013), (3) the joint action (Nassimbeni, 2001), and (4) the innovation process (Rogers, 2004; Ng and Thiruchelvam, 2012).

\section{Cluster firms characteristics}

Finally, the intrinsic factors of cluster firms affect their performance (Chung and Kalnins, 2001; Canina, Enz and Harrison, 2005). Specialization and human capi- 
tal of the companies are factors that stand out in the literature. Specialization, on one hand, increases the knowledge and competitiveness of the cluster (Nicolini, 2001; Boix and Trullén, 2010; Kamnungwut y Guy, 2012). On the other hand, studies suggest two appropriate ways of managing knowledge: sharing knowledge and improving human capital. The knowledge exchange among employees of companies within the cluster allows the flow of information, which increases their know-how and competitiveness (Bell and Albu, 1999; Gordon and McCann, 2000; Gabaldón-Estevan and Fernández-de-Lucio 2006; Sengün, 2010; Molina-Morales and Expósito-Langa, 2012). Meanwhile, improving human capital through training can expand their expertise and the chances of innovation (Bell and Albu, 1999; Cotic-Svetina, Jaklic and Prodan, 2008; Manning et al., 2010; Hervas-Oliver et al., 2012; Kamnungwut and Guy, 2012).

\section{Clusters in Tamaulipas}

The four cases emerged naturally, and were later supported by public policies that have encouraged regional development. Each cluster has dissimilar implications for public administration, and each one has evolved differently.

\section{Petrochemical cluster}

The petrochemical cluster emerged in 1960 due to the presence of diverse firms in the city of Altamira and the establishment in 1980 of the industrial organization Asociación de Industriales del Sur de Tamaulipas, A. C. (AISTAC). National and international companies are located in this cluster's area, which represents an investment of over 5500 million dollars. Currently, Tamaulipas is the largest plastic resins producer in Mexico, manufacturing over two million tons per year, which represents $70 \%$ of the installed capacity in the country. Moreover, $30 \%$ of private production of chemicals and petrochemicals is generated in the Altamira area. The entire synthetic rubber production for domestic or foreing consumption originates from this cluster; hence, this is the largest petrochemical cluster ${ }^{1}$ in Mexico.

It is one of the most important clusters in the state of Tamaulipas, representing $4.79 \%$ of the state GDP (INEGI, 2012) and is formally comprised by twenty companies in the petrochemical and derivative sectors, most of them being

\footnotetext{
${ }^{1}$ For more information consult: http://www.puertoaltamira.com.mx.
} 
large international and national organizations: Perfiles KB, Tepeal, PPG Industries, Royal Technologies, Indelpro, M\&g Polímeros de México, Basf, Industrias Negromex, Mexichem Resinas Vinílicas, Policyd, Sabic Innovative Plastics, Polioles, Royal Technologies, Biofilm, Flex Americas, Cryoinfra, Chemtura Corporation, Dupont, Dynasol, and Petrocel Temex. The AISTAC organization manages the cluster, promotes and strengthens synergies among its members. This cluster has the support of four local educational institutions: Instituto Tecnológico de Estudios Superiores de Monterrey, Instituto Tecnológico de Cd. Madero, Universidad Politécnica de Altamira, and Universidad Tecnológica de Altamira.

\section{Auto parts cluster}

The auto parts industry in 2008 represented $5.7 \%$ of state GDP and $6.8 \%$ sector jobs nationwide (INEGI, 2009). The Tamaulipas border ranked fifth in national establishments and workers in auto parts and electrical-electronics industries. In addition, in April of 2012, 365 manufacturing establishments were registered in Tamaulipas, 120 of the auto parts industry. ${ }^{2}$ The auto parts cluster was formally consolidated in May of 2009 in Matamoros, located in the northern part of the state, near the United States-Mexico border. Some of the cluster firms have been in the region for twenty-five or thirty years. This cluster is constituted by ten companies: Deltronics, FFw de México, Fisher Dynamics (two plants), Industrias Gobar, Inteva (two plants), ks Centoco, Magnesium Aluminium, and Productos Electromecánicos BAC. Also, it is supported by three local educational institutions: Instituto Tecnológico de Matamoros, Universidad Tecnológica de Matamoros, and Universidad Autónoma de Tamaulipas. Founded in 1972, the industrial organization Asociación de Maquiladoras de Matamoros, A. C. (AMMAC) has been one of its principal drivers. The AMMAC represents the interests of its members and encourages their development. In addition, the state public agency Secretaría de Desarrollo Económico y del Empleo (SEDEEM) has contributed to the cluster's consolidation by establishing its formal management.

\section{Electric-electronic cluster}

The northeastern Mexico area (the states of Coahuila, Chihuahua, Nuevo León and Tamaulipas) concentrates 50 economic units (including plants and sales

\footnotetext{
${ }^{2}$ For more information consult: http://sietam.tamaulipas.gob.mx.
} 
offices) of the 777 units in the country in the electronics sector. In Tamaulipas, the electric-electronic subsector contributes to $20.2 \%$ of the manufacturing industry (INEGI, 2010). The electric-electronic cluster was formally created in May of 2007 in the city of Reynosa, which borders the United States. It embraces ten companies: Nokia, Delphi, Jabil, HD Electronics, LG, Foxconn Reynosa, Motores Reynosa Emerson, Motorola de Reynosa, Alcom, and TRW Electrónica Ensambles. Likewise, three educational institutions participate with this cluster: Instituto Internacional de Estudios Superiores, Universidad Tecnológica de Tamaulipas, and Universidad Autónoma de Tamaulipas. Also, the SEDEEM has had an equally important role in the growth of this cluster. In addition, the industrial organization Reynosa Asociación de Maquiladoras y Manufactureras, A. C. (RAMmaC) has strengthened this cluster. Among its mission, the RAMMAC seeks to promote cooperation among its members, share information, improve techniques and strategies, and attain communication and cooperation within the local community.

\section{Information technology cluster}

According to the Directorio Estadístico Nacional de Unidades Económicas (INEGI, 2003), there are 3237 economic units of the information technology (IT) sector in the country; $53 \%$ of these concentrated in four states (Distrito Federal, Nuevo León, Jalisco and Estado de México). Tamaulipas is among the regions with less than $1 \%$ of economic units in the country. The information technology cluster in Tamaulipas (cluster TITAM) emerged on June 27, 2005, due to the initiative of four entrepreneurs; this cluster's base is located in city of Tampico. It obtained formal status as a cluster in June 2007. The cluster is comprised of more than seventeen members that are primarily small and medium-sized enterprises: Infovic, Computadoras y Sistemas de Victoria, Acesa, Integra, Consultores en Sistemas, Dipros Systems, Fortia Technology, Sofcom, Cuarto de Guerra, MG Asesores en Informática, Cuasar Systems, Grupo Eikros, Sistema de Software, Dialect, E-one Business, IDE Network, and sIs Logística. Eight educational institutions in the state support this cluster as well: Universidad Autónoma de Tamaulipas, Instituto de Ciencias y Estudios Superiores de Tamaulipas, Universidad Tecnológica de Altamira, Instituto Tecnológico de. Madero, Universidad Politécnica de Victoria, Instituto Tecnológico de Victoria, Centro de Investigación y Estudios Avanzados del Instituto Politécnico Nacional, and Universidad La Salle. 


\section{RESEARCH METHODOLOGY}

This study is mainly exploratory with interest in identifying the factors that are involved in a cluster's performance. Consistent with previous studies focusing on clusters performance (Saxenian, 1995; Gordon and McCann, 2000; Colgan and Baker, 2003; Kim, 2005; Lembke and Östhol, 2005; Gabaldón-Estevan and Fernández-de-Lucio 2006; Silvestre and Tavares, 2009; Manning et al., 2010; Sengün, 2010; Kamnungwut and Guy, 2012; Ng and Thiruchelvam, 2012; Richardson, Yamin and Sinkovics, 2012) a case study approach ${ }^{3}$ based on qualitative methodology was chosen for the research.

Several studies have discussed the validity of case studies, mentioning among its attributes the attainment of a richly detailed 'portrait' of a phenomenon (Hakim, 2000), usefulness to investigate contemporary phenomenon within a real-life context (especially when boundaries between the phenomena and the context are not clearly evident) (Yin, 2003), and valuable in applying solutions to current problems based on past problem-solving experiences (Sekaran, 2003). Also, case studies are appropriate for understanding certain phenomena and in generating theories for empirical testing ( $\mathrm{Ng}$ and Thiruchelvam, 2012).

Due to the nature and variety of what has been defined as a cluster, we assumed a definition that includes a geographically concentrated reality that integrates diverse businesses and institutions (learning and related) and is maintained by an active industrial association with a strong and explicit culture of a cluster. As Glaser and Strauss (1967) suggested, the sample was determined with respect to the criteria of heterogeneity, and following the homogeneity guidelines developed by Yin (2003), who insists on the importance of logic of replication (cases that are as similar as possible to enhance the validity of the research).

The analyses were carried out from June of 2009 to August of 2010, starting with the study of their main characteristics. The main data collection for this study was obtained through in-depth interviews with representatives from the main actors of each cluster (especially those who regularly attend cluster meetings). We contacted five members of the petrochemical cluster: three companies, an industrial association, and a government agency. Nine members of the auto parts cluster were interviewed: seven companies, an industrial association, and an educational institution. In the electric-electronic cluster, we

\footnotetext{
${ }^{3}$ Considered relevant for research that attempts to identify patterns and develop hypotheses (Eisenhardt, 1989; Meredith, 1998; Yin, 2003).
} 
communicated with eight members: six companies, an industrial association, and an educational institution. We had access to thirteen members of the information technology cluster: nine companies, three educational institutions, and one research institute.

Two researchers conducted each semi-structured interview with members of the companies and organizations directly involved with the cluster associations (e.g., CEO, director of human resources, manager, etc). Each session lasted between 60 to 90 minutes, and every interview was tape-recorded. Interviewees were assured that their identities would be confidential (anonymity). The interview sessions followed a pre-designed interview protocol. First, the participants were provided with a brief description of this research. This was followed by questions regarding: (1) factors related to the clusters economic, social, and political environment; (2) the significance and roles of various clusters actors; and (3) factors related to cluster firms. The main goal was to evaluate how these were influencing the clusters performance.

The compilation and triangulation of different secondary data from documents, websites and press releases along with direct observation during the site visits provided essential data on the four clusters. The interviews were transcribed and coded by an undergraduate student familiar with industrial cluster literature and with case writing. The coded transcriptions (organized acording to the sequence of topics in interviews) and the recordings were reviewed and the transcriptions were adapted. The interviewees read and commented on the protocols and our assessments, which generated minor observations.

\section{FINDINGS}

In this section, we present our case base findings regarding the presence of the three factors on clusters performance. We first analyze the impact of the environmental factors, and then those related to the characteristics of the cluster itself and, finally, those of cluster firms. In order to respect the anonymity of the participants, we used a two or three letter and a number key to identify them. The first letter determines whether it is a corporation, an association or a government agency (E for company, A for association, and o for government organization). As to the last letter, it indicates the sector: A for auto parts, P for petrochemicals, E for electric-electronic and IT for information technology). Finally, the number in the code points the number on our list of respondents for each category. 


\section{Environmental factors}

Based on literature review, we found of that there are arguments mentioning that the location a cluster can enhance its operation. These findings have been organized in four categories: a) geographic location, b) public policies, c) sociocultural identity, and d) local demand.

\section{a) Geographic location}

As was previously outlined, there are arguments acording to which the context of industrial clusters, the geographic location has a relevant role. As suggested in literature, clusters location can provide economies of agglomeration due to shared resources and connectedness to other cluster firms (Folta, Cooper and Yoonsuk, 2006; Soler, 2006; Silvestre and Tavares, 2009; Diez-Vial, 2011; Libaers and Meyer 2011; Li and Geng, 2012; Mukim, 2012; Molina-Morales and Expósito-Langa, 2012; Munari, Sobrero and Malipiero, 2012). Also, Pandit and Cook (2005) and Liao (2010) argue that the competitiveness of the region is an important determinant of firms achievements.

In our case studies, we find that respondents of the auto parts cluster allude that the proximity to the United States and the availability of diverse product and service companies interconnected to the sector ease the positioning of companies. Matamoros is considered a good location, as the general manager of the EA4 company points out: "This location [Matamoros] is important because we are really close and we serve all companies that are around, that's the main advantage we have". Similarly, regarding this cluster's location, the EA5 plant manager states: "All of us involved here provide different products to the auto parts industry, so the location is excellent."

Also, Reynosa is considered by interviewees as an appropriate location for the electric-electronic cluster. As the AE1 organization director notices: "The electrical-electronic cluster in Reynosa is justified by the presence of tractor companies like LG Electronics and Nokia. They make the region very important, hence the number of firms setting up here." Moreover, for this cluster, proximity to the border with USA is suitable, as the human resource manager of the EE6 company mentioned: "The border has a big investment, and we have seaports nearby; infrastructure that is attractive to investors." In this way, the human resources manager of the EE6 company expresses: "Being in a border area has a great impact on our performance, [it] is a focal point to facilitate free trade." 
In addition, the geographical location of the petrochemical cluster produces location advantages from the proximity to Altamira port, which is identified by interviewees as ideally suited for shipments. ${ }^{4}$ As the EP1 plant manager says: "We are close to the primary chemicals terminal in Mexico, it is very important to supply our warehouses." This is affirmed by the materials and logistics manager of company EP2: "This location allows sending material in a transit time of one or two days, or even less to the domestic market; the harbor is 15 minutes away."

Likewise, it is important to mention that the large pool of graduates in the petrochemical, electric-electronic, and information technology clusters area and of skilled labor in the auto parts cluster result from the specialized universities and technical institutions found in the state. Except for the IT cluster (which is in earlier stages of development), the rest of them enclose international and national corporations with more than twenty or thirty years of existence in the region. On one hand, this fact is highlighted by the human resources director of company EE4: "We are a high-tech company, we need people with good training and here we have good universities. It is an advantage to have this diversity of schools in the area". The human resources director of the EE5 company has this to say: "The human factor of the area has adapted to all of the models that the company has sought to implement." In the same way, the EE1 association director says: "The city has education institutions participating in the cluster, it has the necessary educational infrastructure... 20 years ago, Reynosa did not have enough human capital. The city has now a great advantage: with work ethic, not only with globally recognized quality but confidence in the quality of labor."

On the other hand, the director of the EIT 7 company of the IT cluster mentions: "There are very capable people in the area, there are outstanding people." Meanwhile, in the auto parts cluster the AA1 association director mentions: "There is great availability of labor in Matamoros; in particular, we have experiences of a very strong work ethic." Additionally, due to the geographic location advantages and conditions, the IT and petrochemical clusters companies can access lower production costs (e.g., water costs in the Altamira region). This is stated by the CEO of EIT9 company of the IT cluster: "Our operating costs are $30 \%$ less than in a large city of the country."

\footnotetext{
${ }^{4}$ It is important to mention that most companies are part of a foreign company and are not in charge of direct foreign sales.
} 
In agreement with findings in the literature (Baptista and Swann, 1998; Pandit and Cook, 2005), we observe that these clusters locations create access to valuable resources (pool of skilled labor), and assistance agents (diversity of companies, international bridge, maritime port, lower production costs) that enhances clusters performance.

\section{b) Public policies}

Public policies are regarded as central support to ease new start-ups and boost innovative research (Romijn and Albaladejo, 2002; Manning et al., 2010). Yamawaki (2002) supports the notion that high-tech venturing needs the active roles of companies and knowledge centers along with government agencies (e.g., through the creation of specialized offices).

Meanwhile, some researchers argue that government policies can enhance and facilitate localization activities to encourage network involvement and international foreign firms investments that, in turn, create local collective efficiency (Kim, 2005; Nishimura and Okamuro, 2011; Barbieri, Tommaso. and Bonnini, 2012; Richardson, Yamin and Sinkovics, 2012). Our case analysis reveals that only in the IT cluster a national policy that fosters software development (research and development) had a turning point for it. As mentioned by the EIT 7 company's CEO: "Without the PROSOFT ${ }^{5}$ program this cluster may not have existed."

\section{c) Sociocultural identity}

Nassimbeni (2001), Nicolini (2001), and Liao (2010) claim that one of the most important factors in cluster performance is the sociocultural identity of cluster firms. Literature suggests that collective action is necessary for clusters success (Cotic-Svetina, Jaklic and Prodan, 2008; Kong, 2011; Nishimura and Okamuro, 2011; Kamnungwut and Guy, 2012; Molina-Morales et al., 2012; Nakwa, Zawdie and Intarakumnerd, 2012; Ng and Thiruchelvam, 2012; Gebreeyesus and Mohnen, 2013). As suggested in the literature, the sociocultural identity allows knowledge and resource sharing (Nassimbeni, 2001; Liu, 2011).

\footnotetext{
${ }^{5}$ PROSOFT is a public program for the development of the software industry carried by the Tamaulipas state government, through the Secretaría de Desarrollo Económico y Turismo together with the Secretaría de Economía of the Mexican federal government (http://tamaulipas.gob.mx/ prosoft-2012 /).
} 
In our case studies we found out that, in most clusters, sociocultural identity in the form of collective action takes place. In the IT cluster, five early members created together a new company and regularly develop joint services (innovative capacity) due to regular informal meetings for information sharing (e.g., potential clients and trends). As the director of company EITI5 mentions: "We created the first school of robotics in the region among several companies of the cluster."

Meanwhile, the auto parts cluster members have monthly meetings that are planned by the AMMAC and are regarded as important opportunities to learn about newly established firms. As the general manager of the EA4 company reveals: "There are many companies that sell to each other here in Matamoros. Nobody knows what you do until you approach through AMMAC." Furthermore, as underlined by the EA5 plant manager, this factor is important among the automotive cluster companies: "We believe that we are members of the AMMAC, we all share that, and through the association we seek help." However, sociocultural identity is stronger among companies of the same size, as revealed by the director of the AA1 association: "We share a general culture among large companies, but not among small ones... Although I feel that employers in Matamoros are more united than in any other city, (I have participated in other initiatives). The credit goes to the AMMAC, it does an excellent job keeping up the cohesion between the different companies."

Similarly, in the petrochemical cluster, companies benefit from proximity to practice benchmarking and collective problem solving. As mentioned by the EP3 plant manager: "We learn from different corporations, this helps the enterprises growth and competitiveness." In sum, our case studies reveal the importance of collective action to acquire a better performance. Although, it is important to mention that belonging to a cluster does not assure the interaction of cluster members. In fact, on our findings it is shown that knowledge sharing is discretionary, and limited by the secrecy level and absorptive capacity of the recipient (i.e., skills and capabilities) (Kamnungwut and Guy, 2012; Molina-Morales et al., 2012). Too Cotic-Svetina, Jaklic, and Prodan (2008) sustain that firms also need to create and nurture links outside the cluster to further foster performance.

\section{d) Local demand}

The size of the local demand (or home market) affects the intensity of trade flows and performance (Rabellotti, 1997; Nicolini, 2001; Diez-Vial, 2011). In our case 
studies, only in the IT cluster the scarce local demand forces many software companies to search clients throughout the country. Furthermore, interviewees mentioned the presence of potential markets in the state (e.g., application services and small to medium-sized companies in the northern area of the state). Thus, indicated by the ETIC 7 company director: "Our strategy is to have our production base in Tampico and marketing offices in other cities."

The fact that our case studies partly support the findings of Rabellotti (1997), Nicolini (2001) and Diez-Vial (2011) may be due to the lack of a higher demand in each cluster's home market or the nonexistence of direct sales (international corporations) which leads to search markets outside their region. All things considered, as it was outlined in our section and case studies regarding the clusters geographical location, we propose that environmental factors have an important role on clusters performance. In sum, we offer the following proposition:

Proposition 1: Environmental factors like: strategic location, R\&D policies, pool of specialized companies, low production costs, joint ventures action, and unattended markets impact positively on industrial clusters performance.

\section{Factors related to clusters' characteristics}

In the following lines we present the effects concerning three features of an industrial cluster: a) relation with universities, b) internal services, and c) internal networks.

\section{a) Relationship with universities}

The cooperation between clusters and universities has been emphasized in the literature as significant, either for knowledge transfer or for infrastructure support (Romijn and Albaladejo, 2002; Albino, Carbonara and Giannoccaro, 2005), or as an important source of innovative spin-outs (Libaers and Meyer, 2011), and of expertise (Manning et al., 2010).

Participants of all clusters agree that regional universities are an important source of skilled labor. Moreover, in the petrochemical, auto parts and electric-electronic clusters, universities have adapted their career programs to the companies' needs. Additionally, incorporating students in their businesses allows them to spot those who have the required skills for their later employment; the 
electric-electronics and auto parts clusters have frequently taken these opportunities. In this manner, the general manager of the EA4 automaker comments: "Universidad Tecnológica has been involved; they have developed a program focused on the companys' requirements.

In fact, some of their graduates are working in this company." Also, the materials manager of the EE 2 company expressed: "There was an alignment with local universities; they created educational plans focused on specific deficiencies, such as mechanical-electronics, a career that did not exist before." In addition, in the auto parts cluster the AAl association director emphasizes: "Universities in the region have developed certain programs, such as the certifications of welders and electronic technicians. They have responded to certain business needs."

In sum, our findings are partly consistent with those of Albino, Carbonara and Giannoccaro (2005) and Romijn and Albaladejo (2002); universities that are close to clusters are sources of graduates with skilled knowledge, but a closer approach with cluster companies is further needed in order to accomplish a better knowledge transfer (Manning et al., 2010; Libaers and Meyer, 2011). Our findings also show the region lacks research institutions, which literature has proven as an important factor in upgrading clusters performance (Romijn and Albaladejo, 2002; Albino, Carbonara and Giannoccaro, 2005; Hervas-Oliver et al., 2012; Barbieri, Tommaso. and Bonnini, 2012; Nakwa, Zawdie and Intarakumnerd, 2012).

Likewise, although different studies have proven the important role of public agencies as relevant actors in the R\&D process (Yamawaki, 2002; Lembke and Östhol, 2005; Manning et al., 2010), our case studies do not show the presence or differentiated role of these actors.

However, our findings concur with those in Sarvan et al. (2011) that also find a lack of support from the institutions in the environment; and also with those in Ng and Thiruchelvam (2012), that come across the absence of mutual understanding between companies and public institutions. This might be related to the political discontinuities and bureaucratic and limited budget provisions firms observe in government interventions (Nakwa, Zawdie and Intarakumnerd, 2012; Richardson, Yamin and Sinkovics, 2012).

Nevertheless, not all cluster firms are capable of accessing and exploiting knowledge from any kind of research institution due to their level of internal resources and their exploitation (absorptive capacity) (Hervas-Oliver et al., 2012). 


\section{b) Internal services}

Specialized and ad hoc services have been proven to positively affect industrial clusters performance, mainly due to knowledge spillovers and specialization generated inside clusters (Nicolini, 2001; Gabaldón-Estevan and Fernández-deLucio, 2006).

In our case studies, although not formally inside the industrial clusters, we observe internal services have a positive impact on two clusters. On one hand, the Altamira port offers specialized logistics, shipping and maritime terminal services to the petrochemical companies. On the other hand, logistics and shipping companies are situated inside one of the electric-electronic cluster corridors. Also, most participants point out this cluster's monthly meetings as helpful to gather information on new service providers in the region. Thus, the electric-electronic cluster jointly hires service companies, as indicated by the human resources manager of the EE6 company: "Together we hired a consulting group, as well as telephone operators, messaging and raw material suppliers." Thus, our case studies show some evidence of the importance and need of service companies within the clusters, although our case studies lack the vertical integration of service companies.

\section{c) Internal networks}

Networks have been largely stressed in industrial clusters literature as a main engine of their origin, but also of their performance. This is due to enhancement of: (1) skills (Saxenian, 1995; Martínez del Río and Céspedes-Lorente, 2006), (2) knowledge spillovers (Bell, 2005; Fuchs and Koch, 2005; Liao, 2010; Liu, 2011; Kong, 2011; Sarvan et al., 2011; Molina-Morales et al., 2012, Ng and Thiruchelvam, 2012), (3) collective action (Nassimbeni, 2001; Ng and Thiruchelvam, 2012), and (4) the innovation process (Rogers, 2004; Ng and Thiruchelvam, 2012).

Our case studies reveal that internal networks exist in all clusters. The IT cluster interviewees emphasized that trust (prevailing among the software developers located in the south of the state) encouraged the creation of a new company, permanent joint actions, and knowledge spillovers (e.g., refer potential clients and trends). As a respondent (EIT9) mentioned: "The IT cluster could not have been created without these informal relationships... we have this connection due to mutual benefits, this has been a continuous process since at least eight years." 
Likewise, the industrial associations of the auto parts, petrochemical and electric-electronics clusters (AMMAC, AISTAC and RAMMAC, respectively) promote synergies among their own cluster's companies (e.g., joint storage in the auto parts cluster; shipping of raw materials in the petrochemical cluster; and joint training, benchmarking and collective communication with government representatives in the electric-electronic cluster). This is noted by the human resources manager of the EA6 company (automotive cluster): "Most of us do not see each other as enemies; we share tools and information about machinery, or grant temporary labor." Collaboration is also noted by the EA5 auto parts plant manager: "Last year we were working jointly with Delphi, they helped us implement some collective training programs. We visited Trico for the same purpose. That is how we help each other."

In the electric-electronic cluster, the EE2 company's materials manager mentions a cooperation experience for staff training: "We developed a training material. We searched and found that another cluster company had a similar training program, so they sent us the material and we analyzed it together. We made a prototype and combined the two practices and identified the training needs of our company."

In sum, our findings agree with literature (Saxenian, 1995; Nassimbeni, 2001; Rogers, 2004; Bell, 2005) showing the relevance of internal networks in the Tamaulipas industrial clusters performance.

Consequently, our case studies findings add key insights in understanding industrial clusters characteristics in Tamaulipas. Although the lack of knowledge and support institutions (research institutes and government agencies), the relationships inside and outside of the clusters affect its performance (Nishimura and Okamuro, 2011; Richardson, Yamin and Sinkovics, 2012). Accordingly, we develop the following proposition:

Proposition 2: Close relationships with universities, the presence and diversity of service companies and trust among cluster firms have a positive impact on clusters performance.

\section{Factors of cluster companies}

In this section we present the outcomes related to cluster firms: a) specialization and b) improving human capital. 


\section{a) Specialization}

Positive externalities of specialization and industrial clusters performance have been analyzed as strongly complementary; mainly due to the benefits of cooperative production (Nicolini, 2001; Boix and Trullén, 2010). Also, specialization has been stated as a tool for inter-firm knowledge spillovers, as it represents an investment in a reputation for trustworthiness (Kamnungwut and Guy, 2012).

In our analysis, we observe that clusters have the specialization component. The IT cluster has five software developing companies located in south of Tamaulipas that act as an internal network that has fostered the creation of a new company, of commercial associations, and product innovations. The interviewees of the electric-electronic, petrochemical and auto parts clusters mentioned that, because large corporations have been in the area for more than two decades, the creation of infrastructure and industrial associations, and the pool of skilled labor in the area has been stimulated. The EE2 company's material manager (member of the electric-electronic cluster) has this to say about it: "Our company has been here [Reynosa] for twenty years. Hence, the region gives us assurance."

Also, regarding this factor, a member (EA3 plant manager) of the auto parts cluster pointed: "An auto parts cluster cannot be fulfilled without this economic and technological infrastructure found in Matamoros." This is also reflected in the EA3 plant manager's comment: "We are very strong in industry safety, for example, there are not stamping companies in Monterrey. An automotive cluster cannot be fulfilled without the economic and technological infrastructure we have. We are the number one advantage of the United States, we are the industry's niche." In fact, respondents emphasize specialization in the area as determinant for attracting large companies, as highlighted by the director of the AA1 automotive cluster association: "Many companies are looking for low costs, pool of labor, and certain services, which also are available in Reynosa. When taking the location decision there are two or three competing places, in the end they choose Matamoros; perhaps because the cluster is here."

Meanwhile, the petrochemical cluster interviewees mentioned the relevance of access to skilled graduates, mainly due to the presence of technical education institutions as part of the specific infrastructure. As stated by a petrochemical cluster member (EP1 plant manager): "[Petrochemical] companies see that the infraestructure is here [in Altamira] as well as the raw material and the human resources they need." 
Hence, the industrial clusters examined, show evidence of the important effects of specialization mentioned in the literature (Nicolini, 2001; Boix and Trullén, 2010; Kamnungwut and Guy, 2012).

\section{b) Human capital improvement}

Training of labor significantly fosters cluster firms performance as an important element in the reinforcement of firm's resources (Bell and Albu, 1999; CoticSvetina, Jaklic and Prodan, 2008; Manning et al., 2010; Hervas-Oliver et al., 2012; Kamnungwut y Guy, 2012).

In our case studies, we find that improving human capital through training increases companies' productivity in all clusters. The positive impacts mentioned by interviewees include: motivation, acceleration of the learning process, quality (in the electric-electronic cluster), creativity, better relationships with clients and providers, loyalty (in the auto parts cluster), efficiency (in the IT cluster), reduction in the number of accidents, and labor stability (in the petrochemical cluster).

In this manner, the EA 5 plant manager, member of the auto parts cluster, stresses: "Training of our employees is a priority in this company. First, the supervisor identifies the needs of each employee and gets a training matrix. With their training we get competitiveness, which means: higher quality, better manufacturing prices, on time deliveries to customers, close relationship with suppliers, and access to better prices."

Similarly, the electrical-electronics firms confirm the importance of training. This is reflected in the EE5 company's human resources director comment: "Our training programs are focused on very specific technical issues, analysis and problem solving, teamwork, and leadership."

Our findings support the earlier studies of the human capital improvement through training as a relevant practice for clusters performance (Bell and Albu, 1999; Cotic-Svetina, Jaklic and Prodan, 2008; Manning et al., 2010; Hervas-Oliver et al., 2012; Kamnungwut y Guy, 2012). Although knowledge exchange among cluster firms has been stated as an important knowledge spillover channel (Bell and Albu, 1999; Gordon and McCann, 2000; Gabaldón-Estevan and Fernández-de-Lucio 2006; Sengün, 2010; Molina-Morales and ExpósitoLanga, 2012) in our case studies, the rotation of employees is not considered by our interviewees as a positive practice for their performance. Hence, our findings do not show evidence of this factor. 
In sum, our case studies imply that a clusters performance also depends on its firms characteristics (Chung and Kalnins, 2001; Canina, Enz and Harrison, 2005). We suggest that a cluster's development may be hindered by its components. More formally stated:

Proposition 3: The specialization of industrial cluster companies along with human capital training enhances a clusters performance.

\section{CONCLUSIONS AND DISCUSSION}

In recent decades, literature has demonstrated successful examples of industrial competition by creating clusters. Hence, several governments around the world have promoted their creation. The purpose of this research was to analyze the impact of different environmental factors, cluster characteristics, and cluster firms in four clusters performance. Through in-depth case studies of industrial clusters we interviewed 33 members and actors. With this case study methodology, we had in-depth face-to-face meetings that elicit 'softer' evidence on the processes underlying the data drawing on the cluster experience (Pandit and Cook, 2005).

We thereby gain several theoretical insights into the manifestation of clusters performance in this specific context. First, interviews seem to indicate that our clusters geographic position has location economies (Baptista and Swann, 1998), and that sociocultural identity among cluster firms enhances their performance (Nassimbeni, 2001). Moreover, little evidence is shown related to public policies (Manning et al., 2010) and local demand (Rabellotti, 1997; Nicolini, 2001) positive effects.

Second, we provide a somewhat different perspective on clusters characteristics influence. Regarding links to universities, we partly support the literature findings (Romijn and Albaladejo, 2002; Albino, Carbonara and Giannoccaro, 2005), due to partial cooperation (career adjustment and practitioners). Moreover, our findings suggest that internal networks (Saxenian, 1995; Nassimbeni, 2001; Rogers, 2004; Bell, 2005) are an important engine in clusters performance. Although, contrary to literature, we find a lack of research institutes (Romijn and Albaladejo, 2002; Albino, Carbonara and Giannoccaro, 2005) and government agencies (Yamawaki, 2002; Lembke and Östhol, 2005) that support clusters research development. Also, in contrast to cluster literature, we find absence of service companies (Nicolini, 2001) as formal cluster members in our case stu- 
dies. In fact, our findings show that knowledge sharing is discretionary, and limited by the secrecy level and absorptive capacity of the recipient (Kamnungwut and Guy, 2012; Molina-Morales et al., 2012).

As for cluster firm's characteristics, we add evidence that supports clusters research that emphasizes the effects of specialization as a source of competitiveness (Piore and Sabel, 1984) and of training as a resource of expertise (Bell and Albu, 1999; Cotic-Svetina, Jaklic and Prodan, 2008). In contrast to literature findings (Bell and Albu, 1999), our case studies perceive human capital rotation as a negative practice.

Our research is not without limitations. We are aware that this methodology is limited in terms of its explicative power. However, our interpretations and propositions, analytically generated instead of statistically generated, were derived through rigorous research. Additionally, as our cases all stem from the same cultural background (Mexico), the applicability of our results to clusters from other countries may be limited. Even though this is a qualitative study, it has contributed to the understanding of a phenomenon that is difficult to quantify (Colgan and Baker, 2003). Additionally, conducting a comparative study (limited in its explicative power) adds to the cost-benefit analysis of adopting clusters as a regional development strategy (Barkley and Henry, 2001). Certainly, this investigation is a launching pad for future studies that examine clusters performance. Specially, more in depth case studies are needed, but also quantitative studies than can help to generalize findings. Thus, we hope to inspire future and present industrial clusters with our findings and propositions. In this way, we could fulfill our goal of giving back to the field that has enriched our work.

\section{REFERENCES}

Albino, V., Carbonara, N. and Giannoccaro, I. (2005). Industrial districts as complex adaptive systems: Agent-based models of emergent phenomena. In: C. Karlsson, B. Johansson and Roger R. Stough (eds.), Industrial Clusters and InterFirm Networks. Cheltenham, uk: Edward Elgar, pp. 58-82.

Baptista, R. and Swann, P. (1998). Do firms in clusters innovate more? Research Policy, 27(5), pp. 525-540.

Barbieri, E., Tommaso, M. R. and Bonnini S. (2012). Industrial development policies and performances in Southern China: Beyond the specialized industrial cluster program. China Economic Review, 23(3), pp. 613-625.

Barkley, D. L. and Henry, M. S. (2001). Advantages and disadvantages of targeting in- 
dustry cluster. REDRL Research Report 09-2001-01. Regional Economic Development Research Laboratory: South Carolina, Clemson University.

Bathelt, H. (2001). Regional competence and economic recovery: Divergent growth paths in Boston's high technology economy. Entrepreneurship and Regional Development, 13(4), pp. 287-314.

Beaudry, C. and Breschi, S. (2003). Are firms in clusters really more innovative? Economics of Innovation and New Technology, 12(4), pp. 325-342.

Becattini, G. (1987). Mercato e Forze Locali: Il Distretto Industrial. Il Mulino, Bologna.

Bell, G. G. (2005). Research notes and commentaries: Clusters, networks, and firm innovativeness. Strategic Management Journal, 26(3), pp. 287-295.

Bell, M. and Albu, M. (1999). Knowledge systems and technological dynamism in industrial clusters in developing countries. World Development, 27(9), pp. 17151734.

Boix, R. and Trullén, J. (2010). Industrial districts, innovation and I-district effect: Territory or industrial specialization? European Planning Studies, 18(10), pp. 17071729.

Canina, L., Enz, C. A. and Harrison, J. S. (2005). "Agglomeration effects and strategic orientations: Evidence from the us: Lodging industry", Academy of Management Journal, 48(4), pp. 565-581.

Chung, W. and Kalnins, A. (2001). Agglomeration effects and performance: A test of the Texas lodging industry. Strategic Management Journal, 22(10), pp. 969-988.

Colgan, C. and Baker, C. (2003). A framework for assessing cluster development, Economic Development Quarterly, 107(4), pp. 352-366.

Cotic-Svetina, A., Jaklic, M. and Prodan, I. (2008). Does collective learning in clusters contribute to innovation? Science and Public Policy, 35(5), pp. 335-345.

Dávila Flores, A. (2008). "Los clusters industriales del noreste de México (1993-2003). Perspectivas de desarrollo en el marco de una mayor integración económica con Texas. Región y Sociedad, 20(41), pp. 57-88.

Diez-Vial, I. (2011). Geographical cluster and performance: The case of Iberian ham". Food Policy, 36(4), pp. 517-525.

Edquist, C. and McKelvey, M. (2000). Systems of Innovation: Growth, Competitiveness and Employment. Cheltenham, uK: Edward Elgar.

Eisenhardt, K. (1989). Building theories from case study research. Academy of Management Review, 14(4), pp. 532-550.

Folta, T., Cooper, A. and Yoon-suk, B. (2006). Geographic cluster size and firm performance, Journal of Business Venturing, 21(2), pp. 217-242. 
Freeman, C. (1987). Technology Policy and Economic Performance: Lessons from Japan. New York: Pinter.

Fuchs, G. and Koch, A. (2005). Biotechnology and multimedia: Cluster development in new industries. In: C. Karlsson, B. Johansson and R. R. Stough (eds.). Industrial Clusters and Inter-Firm Networks. Cheltenham, UK: Edward Elgar, pp. 231-259.

Gabaldón-Estevan, D. and Fernández-de-Lucio, I. (2006). Influencia de la estructura de los distritos en su capacidad de innovación. Paper at the XVI Congreso Nacional de Asociación Científica de Economía y Dirección de Empresa, 10-12 September, Valencia, Spain.

Gebreeyesus, M. and Mohnen, P. (2013). Innovation performance and embeddedness in networks: Evidence from the ethiopian footwear cluster. World Development, 41(C), pp. 302-316.

Glaser, B. G. and Strauss, A. L. (1967) The Discovery of Grounded Theory: Strategies for Qualitative Research. New York: Aldine De Gruyter.

Gordon, I. and McCann, P (2000) Industrial clusters: Complexes, agglomeration and/or social networks? Urban Studies, 37(3), pp. 513-532.

Grando, A. and Belvedere, V. (2006). District's manufacturing performances: A comparison among large, small-to-medium-sized and district enterprises. International Journal of Production Economics, 104(1), pp. 85-99.

Hakim, C. (2000). Research Design: Successful Design for Social and Economic Research. Routledge: London.

Hervas-Oliver, J. L., Albors-Garrigos, J., Miguel, B. de, and Hidalgo, A. (2012). The role of a firm's absorptive capacity and the technology transfer process in clusters: How effective are technology centers in low-tech clusters? Entrepreneurship \& Regional Development, 24(7-8), pp. 523-559.

INEGI (2009). Censos Económicos 2009. Avalaible at: http://www.inegi.org.mx/est/ contenidos/espanol/proyectos/censos/ce2009/default.asp?s=est\&c=14220. [Accessed 30 September 2009].

(2010). Censos Económicos. Avalaible at: www.inegi.org.mx/est/contenidos/ Proyectos/ce/Default.aspx. [Accessed 10 October 2010].

- (2012). Censos Económicos. Avalaible at: www.inegi.org.mx/est/contenidos/ Proyectos/ce/Default.aspx. [Accessed 15 March 2012].

(2013). Directorio Estadístico Nacional de Unidades Económicas. Avalaible at: http://www3.inegi.org.mx/sistemas/mapa/denue/default.aspx. [Accessed $30 \mathrm{Au}-$ gust 2013].

Kamnungwut, W. and Guy, F. (2012). Knowledge in the air and cooperation among 
firms: Traditions of secrecy and the reluctant emergence of specialization in the ceramic manufacturing district of Lampang, Thailand. Environment and Planning $A_{\text {, }}$ 44(7), pp. 1679-1695.

Karim, S. and Mitchell, W. (2000). Path-dependent and path-breaking change: Reconfiguring business resources following acquisitions in the us medical sector, 19781995. Strategic Management Journal, 21, pp. 1061-1081.

Keeble, D., Lawson, C., Moore, B. and Wilkinson, F. (1999). Collective learning processes, networking and 'institutional thickness' in the Cambridge region. Regional Studies, 33(4), pp. 319-331.

Kim, J. Y. (2005). The formation of clustering of direct foreign investment and its role of inter-firm networks in China: Case study of Qingdao development zones. In: C. Karlsson, B. Johansson and R. R. Stough (eds.). Industrial Clusters and InterFirm Networks. Cheltenham, UK: Edward Elgar, pp. 390-412.

Kong, X. (2011). Why are social network transactions important? Evidence based on the concentration of key suppliers and customers in China. China Journal of Accounting Research, 4(3), pp. 121-133.

Krugman, P. (1991). Geography and Trade. Cambridge, MA: MIT Press.

Lee, T. L. and Von Tunzelmann, N. (2005). A dynamic analytic approach to national innovation systems: The IC industry in Taiwan. Research Policy, 34(4), pp. 425440.

Lembke, J. and Östhol, A. (2005). Regional partnerships for the biotech sector: North Carolina and Sweden. In: C. Karlsson, B. Johansson and R. R. Stough (eds.). Industrial Clusters and Inter-Firm Networks. Cheltenham, uK: Edward Elgar, pp. 361-389.

Li, J. and Geng, S. (2012). Industrial clusters, shared resources and firm performance, Entrepreneurship \& Regional Development, 24(5-6), pp. 357-381.

Liao, T. J. (2010). Cluster and performance in foreign firms: The role of resources, knowledge, and trust. Industrial Marketing Management, 39(1), pp. 161-169.

Libaers, D. and Meyer, M. (2011). Highly innovative small technology firms, industrial clusters and firm internationalization. Research Policy, 40(10), pp. 1426-1437.

Liu, C. H. (2011). The effects of innovation alliance on network structure and density of cluster. Expert Systems with Applications, 38(1), pp. 299-305.

Lundvall, B. A. (1992). National Systems of Innovation: Towards a Theory of Innovation and Interactive Learning. New York: Pinter.

Maillat, D., Lecoq, B., Nemeti, F. and Pfister, M. (1995). “Technology district and innovation: The case of the Swiss Jura Arc. Regional Studies, 29(3), pp. 251-263.

Malmberg, A., Malmberg, B. and Lundequist, P. (2000). Agglomeration and firm perfor- 
mance: Economies of scale, localisation, and urbanisation among Swedish export firms. Environment and Planning A, 32, pp. 305-321.

Manning, S., Ricart, J. E., Rosatti Rique, M. S. and Lewin, A. Y (2010). From blind spots to hotspots: How knowledge services clusters develop and attract foreign investment. Journal of International Management, 16(4), pp. 369-382.

Marshall, A. (1919). Industry and Trade. London: MacMillan.

(1920). Principles of Economics. New York: MacMillan.

Martínez del Río, J. and Céspedes-Lorente, J. (2006). Generación y difusión de la innovación en distritos industriales. Madri $+d, 3$ (mayo-junio) [on line]. Avalaible at: http://www.madrimasd.org/revista/revista36/tribuna/tribuna3.asp. [Acccesed 15 January 2007].

Masiá, E., Albors, J., Golf, E. and Capó, J. (2004). Identificación de los factores clave de éxito en un microcluster. El caso del textil-hogar en la Comunidad Valenciana, Paper at the Congreso Nacional de la Asociación Científica de Economía y Dirección de Empresa, 19-21 September, Murcia, Spain.

McCann, P. (2008). Agglomeration economics. In: C. Karlsson (ed.). Handbook of Research on Cluster Theory. Cheltenham, UK: Edward Elgar, pp. 23-38.

Menzel, M. P. (2005). Networks and technologies in an emerging cluster: The case of bioinstruments in Jena. In: C. Karlsson, B. Johansson and R. R. Stough (eds.). Industrial Clusters and Inter-Firm Networks. Cheltenham, uK: Edward Elgar, pp. 413-449.

Meredith, J. (1998). Building operations management theory through case and field research. Journal of Operations Management, 16(4), pp. 441-454.

Mixteo Grajirena, J., Idigoras Gamboa, I. and Vicente Molina, A. (2004). Los clusters como fuente de competitividad: El caso de la Comunidad Autónoma del País Vasco. Cuadernos de Gestión, 4(1), pp. 55-67.

Molina-Morales, F. X. and Expósito-Langa, M. (2012). The impact of cluster connectedness on firm innovation: R\&D effort and outcomes in the textile industry. Entrepreneurship \& Regional Development, 24(7-8), pp. 685-704.

Molina-Morales, F. X., Capó-Vicedo, J., Tomás-Miquel, J. V. and Expósito-Langa, M. (2012). Análisis de las redes de negocio y de conocimiento en un distrito industrial. Una aplicación al distrito industrial textil valenciano. Cuadernos de Economía y Dirección de la Empresa, 15(2), pp. 94-102.

Mukim, M. (2012). "Does agglomeration boost innovation? An econometric evaluation. Spatial Economic Analysis, 7(3), pp. 357-380.

Munari, F., Sobrero, M. and Malipiero, A. (2012). Absorptive capacity and localized spi- 
llovers: Focal firms as technological gatekeepers in industrial districts. Industrial and Corporate Change, 21(2), pp. 429-462.

Nahapiet, J. and Ghoshal, S. (1998). Social capital, intellectual capital, and the organizational advantage. Academy of Management Review, 23(2), pp. 242-266.

Nakwa, K., Zawdie, G. and Intarakumnerd, P. (2012). Role of intermediaries in accelerating the transformation of inter-firm networks into triple helix networks: A case study of SME-based industries in Thailand. Procedia-Social and Behavioral Sciences, 52(0), 52-61.

Nassimbeni, G. (2001). Technology, innovation capacity, and the export attitude of small manufacturing firms: A logit/tobit model. Research Policy, 30(2), pp. 245-262.

Nelson, R. R. (1993). National Innovation Systems: A Comparative Analysis. Oxford: Oxford University Press.

Nicolini, R. (2001), "Size and performance of local clusters of firms", Small Firms Economics, 17(3), pp. 185-195.

Nielsen, Klaus (2003). Social capital and the evaluation of innovation policies. International Journal of Technology Management, 26(2-4), pp. 205-225.

Nishimura, J. and Okamuro, H. (2011). Subsidy and networking: The effects of direct and indirect support programs of the cluster policy. Research Policy, 40(5), pp. 714-727.

Ng, B. K. and Thiruchelvam, K. (2012). "The dynamics of innovation in Malaysia's wooden furniture industry: Innovation actors and linkages. Forest Policy and Economics, 14(1), pp. 107-118.

Pandit, N. and Cook, G. A. S. (2005). The clustering of the British financial services industry. In: C. Karlsson, B. Johansson and R. R. Stough (eds.). Industrial Clusters and Inter-Firm Networks. Cheltenham, uK: Edward Elgar, pp. 173-199.

Piore, M. and Sabel, C. (1983). Italian small business development: Lessons for us industrial policy. In: J. Zysman and L. Tyson (eds.). American Industry in International Competition: Government Policies and Corporate Strategies, Ithaca, NY: Cornell University Press, pp. 391-421.

(1984). The Second Industrial Divide. New York: Basic Books.

Porter, M. (1990). The Competitive Advantage of Nations. New York: Free Press.

- (1998). Clusters and the new economics of competition. Harvard Business Review, 76(6), pp. 77- 90.

(1999). Cúmulos y competencia. Nuevos objetivos para empresas, Estados e instituciones. In: M. Porter (ed.). Ser competitivo. Nuevas aportaciones y conclusiones. Bilbao: Ediciones Deusto, pp. 203-288. 
Rabellotti, R. (1997). External Economies and Co-operation in Industrial Districts: A Comparison of Italy and México. Basingstoke: MacMillan.

Richardson, C., Yamin, M. and Sinkovics, R. R. (2012). Policy-driven clusters, interfirm interactions and firm internationalisation: Some insights from Malaysia’s Multimedia Super Corridor”. International Business Review, 21(5), pp. 794-805.

Rogers, M. (2004). Networks, firm size and innovation. Small Business Economics, 22(2), pp. 141-153.

Romijn, H. and Albaladejo, M. (2002). Determinants of innovation capability in small electronics and software firms in southeast England. Research Policy, 31(7), pp. 1053-1067.

Sabel, C. F. (1989). Flexible specialization and the re-emergence of regional economies. In: P. Hirst and J. Zeitlin (eds.). Reversing Industrial Decline. New York: Berg, pp. 17-70.

Sarvan, F., Baser, G. G., Köksal, C. D., Durmus, E., Dirlik, O., Atalay, M. and Almaz, F. (2011). Network based determinants of innovation performance in yacht building clusters. Procedia-Social and Behavioral Sciences, 58, pp. 830-841.

Saxenian, A. L. (1995). Redes regionales y adaptación industrial en Silicon Valley y la Ruta 128. Revista Asturiana de Economía, 4(0), pp. 231-253.

Scott, A. J. (1988). "Flexible production systems and regional development: The rise of new industrial spaces in North America and Western Europe. International Journal of Urban and Regional Research, 12(2), pp. 171-186.

Scott, A. J. and Storper, M. (1987). High technology industry and regional development: A theoretical critique and reconstruction. International Social Science Journal, 112 , pp. 215-232.

Sekaran, U. (2003). Research Methods for Business: A Skill Building Approach. New York: John Willey \& Sons.

Sengün, A. E. (2010). Which type of trust for inter-firm learning? Industry and Innovation, 17(2), pp. 193-213.

Silvestre, B. S. and Tavares Dalcol, P. R. (2009). Geographical proximity and innovation: Evidences from the Campos Basin oil \& gas industrial agglomerationBrazil. Technovation, 29(8):, pp. 546-561.

Soler, V. (2006). Nuevas técnicas para la medición del "efecto distrito" en las aglomeraciones industriales. Economía Industrial, 359, pp. 81-87.

Storper, M. and Scott, A. J. (1989). The geographical foundations and social regulation of flexible production complexes. In: J. Wolch and M. Dear (eds.). The Power of Geography: How Territory Shapes Social Life. Boston, MA: Unwin Hyman, pp. 21-40. 
Yamawaki, H. (2002). The evolution and structure of industrial clusters in Japan. Small Business Economics, 18(1-3), pp. 121-140.

Yang, G. and Stough, R. R. (2005). A preliminary analysis of functional clustering: The case of the Baltimore Metropolitan region. In: C. Karlsson, B. Johansson and R. R. Stough (eds.). Industrial Clusters and Inter-Firm Networks. Cheltenham, UK: Edward Elgar, pp. 303-320.

Yeung, H. W. C., Liu, W. and Dicken, P. (2006). Transnational corporations and network effects of a local manufacturing cluster in mobile telecommunications equipment in China. World Development, 34(3), pp. 520-540.

Yin, R. K. (2003). Case Study Research: Design and Methods. Thousand Oaks: California, Sage. 